\title{
Podstata úvahy Rudolfa Pokorného Literární shoda československá a teoretické východiská česko-slovenskej vzájomnosti
}

\author{
Jana Bujnáková (Brno)
}

\begin{abstract}
Abstrakt
Rudolf Pokorný, autor teoretickej úvahy Literární shoda československá, v diele definoval svoj postoj k česko-slovenskej vzájomnosti a predstavil vlastné teoretické stanovisko vychádzajúce z jazykovej otázky. Podporil spisovnú slovenčinu, uznal jej opodstatnenie a pripravil kompromisné, ale do istej miery kontroverzné riešenie. $V$ autorovom chápaní došlo k posunu - myšlienka vzájomnosti nie je viac existenčnou otázkou, ale otázkou d'alšieho vývoja. Venoval sa klúčovým spisom a osobnostiam, snažil sa pokryt' slovenské a české názorové spektrum, sústredil sa na preukázanie súhlasných aj nesúhlasných stanovísk s ohl'adom na spisovný jazyk. Historický význam Pokorného teoretickej úvahy spočíva aj napriek istej idealizácii v tom, že v dobovom diskurze podporil konštituovanie a d’alší rozvoj slovenského literárneho jazyka na základe racionálne argumentovanej existencie slovenčiny ako relevantnej črty národnej identity a prostriedku krásnej literatúry.
\end{abstract}

\section{Kl'účové slová}

Rudolf Pokorný; Literární shoda československá; česko-slovenské vztảahy; vzájomnost'

\section{Abstract \\ The Fundamentals of Rudolf Pokorny's Reflection "Czechoslovak Literary Consensus" and the Theoretical Background of Czech-Slovak Reciprocity}

Rudolf Pokorný, the author of theoretical study Czechoslovak Literary Consensus defined his attitude towards Czech-Slovak reciprocity and presented his own theoretical position based on the language issue. He supported literary Slovak language, acknowledged its justification, and prepared a compromise but to some extent controversial solution. There had been a shift in the author's understanding - the idea of reciprocity is no longer an existential question, but a question of further development. He tried to cover both, the Slovak, and the Czech spectrum of opinions, and focused on proving both positive and dissenting views on the Slovak literary language and its further direction. He supported further development of the Slovak literary language on the basis of rationally argued existence of Slovak language as a relevant feature of national identity and its necessity for the national literature.

\section{Key words}

Rudolf Pokorný; Czechoslovak Literary Consensus; Czech-Slovak relationship; reciprocity 
Rudolf Pokorný sa otázke česko-slovenskej vzájomnosti venoval nielen ako básnik citovo sa vyrovnávajúci s blízkym Slovenskom, ale aj ako teoretik racionálne argumentujúci o výhodách obojstranného poznávania sa. „V Literárni shodě československé vyzval Čechov, aby venovali Slovákom väčsiu pozornost', a to najmä po rakúsko-uhorskom dualizme v roku 1867, ktorý svojim mad’arizačným tlakom ešte oslabil česko-slovenskú vzájomnú spolupatričnost.."1 $\mathrm{S}$ ohladom na prebiehajúce vnútorné diferenciačné procesy v oboch národných literatúrach nebolo prijatie programu vzájomnosti automatické a české a slovenské postoje sa rozchádzali. Česká literatúra polemizovala o národnom a kozmopolitnom smerovaní, v slovenskej literatúre isté indície, vychádzajúce najmä z Martina, naznačovali príklon k ruštine, k čomu sa kriticky vyjadroval aj Pokorný. Napokon napísal teoretickú úvahu $L i$ terární shoda československá (1880)² s cielom jasne definovat’ svoj postoj k česko-slovenskej vzájomnosti, ktorej vyjadril podporu a predstavil vlastné teoretické stanovisko vychádzajúce z jazykovej otázky. ${ }^{3} \mathrm{~V}$ spise podporil spisovnú slovenčinu a uznal jej opodstatnenie, čo prispelo k hladaniu nového programového chápania; Pokorný pripravil kompromisné, ale do istej miery kontroverzné riešenie, objasnil teoretické stanoviská a historické dôvody, ktoré viedli k vtedajšiemu stavu. Autorova progresívnost̉ sa prejavila v posune smerom k praktickej podpore, pretože, aby svoje presvedčenia mohol aplikovat aj reálne, vytvoril knižnú edíciu Knihovna československá. Pre Pokorného bol charakteristický prístup zmierenia a hladania alternatív. Českú snahu o vzájomné spojenie vysvetlil povinnostou vychádzajúcou zo slovanskej myšlienky.

Musíme konštatovat', že vyjadrené stanoviská objektívne neodrážali spoločenskú situáciu a tiež sa v nich prejavila istá romantická estetika, ale prednostou bolo, že predstavil reálne formy pomoci. Pokorného program česko-slovenskej vzájomnosti Stanislav Šmatlák označil kompromisným riešením, v dôsledku čoho bol prejavený slovenský skepticizmus do istej miery odôvodnený, najmä s ohladom na jazykovú otázku. ${ }^{4}$ Je nevyhnutné objasnit, že Pokorného programu prejavovali podporu Adolf Heyduk (ako tichý spoluzakladatel' Knihovny) a Jaroslav Vlček, ktorý editoval Spevy Jána Bottu 5 a bol autorom druhého zväzku edície Knihovna československá 6 . Všetci traja si uvedomovali, že predložený program nepredstavuje dokonalé riešenie, ale sám Pokorný o ňom hovoril ako o možnom dočasnom riešení. Reflektoval aj náboženský vplyv a rozdielne postavenie slovenčiny medzi dvoma hlavnými slovenskými vierovyznaniami. Vychádzal z argumentu, že aj Martinom Hattalom realizovanú úpravu slovenského jazyka si bude treba osvojit.

1 ZELENKOVÁ, Anna: Medzi vzájomnostou a nevzájomnost’ou. Sondy do česko-slovenských a slovensko-českých literárnych vzt’ahov. Praha - Nitra: Slovanský ústav AV ČR, v. v. i. - FF UKF, 2009, s. 73.

2 POKORNÝ, Rudolf: Literárni shoda československá. Praha: Slavík a Borový, 1880.

3 Podrobnejšie porov. BUJNÁKOVÁ, Jana: Odraz česko-slovenských vztahovv v diele Rudolfa Pokorného. Dizertačná práca. Brno: FF Masarykovy univerzity, 2020, s. 76.

4 ŠMATLÁK, Stanislav: Dejiny slovenskej literatúry II. 3. vyd. Bratislava: Literárne informačné centrum, 2001, s. 174-146.

5 BOTTO, Ján: Spevy Jána Bottu. Praha: Slavík a Borový, 1880.

6 VLČEK, Jaroslav: Literatura na Slovensku, jeji vznik, rozvoj, význam a úspěchy. Praha: Slavík a Borový, 1881. 
Proti mad’arizácii chcel „bojovat““ posilnením slovenčiny (a ochránit ju „spojením s češtinou“), pretože v jej dôsledku dochádzalo k postupnému oslabovaniu celého Slovanstva ${ }^{7}$.

Tematikou Slovenska sa zaoberal aj Josef Holeček a v roku 1880 vydal spis Podejme ruku Slovákưm!, v ktorom sa tiež snažil poukázat’ na dôležitost’ vzájomnej jednoty. K tomu ho inšpirovala cesta na Slovensko v roku 1873, ktoré tak spoznal za iných pomerov ako Pokorný. Slovansky orientovaný Holeček bol takisto ovplyvnený Heydukom a s Pokorným ho spájalo aj členstvo v Uměleckej besede. Pokorný už pri príprave slovanskej antológie oslovil Holečka ${ }^{8}$ a Dunovského a ponúkol im spoluprácu. Antológia mala vychádzat’ v časopise Obrazy života. Vyzval ich, aby „přispěvky z národnich pisni slovan[ských] zasila$l i$ “ ${ }^{9}$ Holeček sa mal v antológii venovat bulharčine, Dunovský srbčine, Pokorný ruštine a pol’štine. Kontakt s Holečkom potvrdil aj Čermákovi v liste z 2. 12. 1877, kde spomenul osobné stretnutie „, hospi̊dce na Vinohradech“.${ }^{10}$ Holečka nazýval priatelom, ale neobišli ich ani dobové nedorozumenia: „Spor Holečkiv se stranou moravskou bezpochyby znáte; jsem již také trochu do něho zapleten. Máme tedy v straně své opět stranu [...] chudou, bezmocnou, nebot’ se ji nedostává povolaných [...]. To plati však jen o básnicich. "11 J. Holeček sa zúčastnil aj výletu, ktorý R. Pokorný zorganizoval pre slovenských študentov v Prahe ${ }^{12}$.

„Holečk viedol k jazykovému kompromisu dôvod, že vedecká literatúra na Slovensku takmer neexistovala, ale poézia a beletria pisaná slovenčinou mala jazykový základ používaný v dialektoch."13 V spise Podejme ruku Slovákům! sa autor postavil za rovnoprávne postavenie Slovákov: „My se prohlašujeme toliko pro vzájemnost', která se zbude podjatosti proti slovenštině a dopreje ji zaslouženého mista po boku češtiny. Strhejme ty umělé hráze, které jsme mezi sebou a Slováky nastavili a splyneme opět $v$ jedno rečiště. "14 Vo svojich vzájomnostných úvahách sa odvolával na tradície Vel'kej Moravy, ktorú chcel symbolicky oživit v duchovnom kontexte: „Nerozštěpujme se dále, sbližme se, kde a kolik je možno a všem stranám prospěšno [...]“ (s. 26). Holečka k napísaniu spisu motivovalo úsilie o dosiahnutie vzájomnej česko-slovenskej zhody, zintenzívnenie spolupráce, chcel prispiet’ k vzájomnému pochopeniu a akceptácii. Jeho cielom bolo rehabilitovat’ vzájomný vztah, spis mal ukončit pretrvávajúci útlm a vyzvat' k aktívnemu udržiavaniu literárnej vzájomnosti (s. 24): „[...] aby mohli upotřebovati nářeči všude v krásném písemnictvi jakož i ve spisech prostonárodnich, čili všude tam, kde se má na lid pưsobiti bezprostředne, lehce a rychle" (s. 28). Absenciu vedeckej literatúry na Slovensku (po českom odmietaní) vnímal ako hrozbu ústiacu k možnému príklonu k mad’arskej

7 Pokorný, vychádzajúc z číselných údajov Šemberu o aktuálnych počtoch Slovákov, dal do kontrastu Budilovičovu teóriu o životaschopnosti literatúry pri počte 30 miliónov l’udí. Porov. POKORNÝ, Rudolf: Literární shoda československá. Praha: Slavík a Borový, 1880, s. 16.

8 R. Pokorný v liste J. Holečkovi, 13. 9. 1872. Uložené v LA PNP v Prahe, fond Holeček Josef.

9 POKORNÝ, Rudolf: Op. cit., s. 16.

10 R. Pokorný v liste J. Holečkovi, 2. 12. 1878. Uložené v LA PNP v Prahe, fond Holeček Josef.

11 R. Pokorný v liste A. Heydukovi, 18. 3. 1879. Uložené v LA PNP v Prahe, fond Heyduk Adolf.

12 „A s R. Pokorným přicházívali literáti i umělci. Pamatuji se, že to býval Jos. Holeček, spisovatel, K. Krejčik, illustrátor, J. Botto, Hurban Svetozár, básnickým jménem Vajanský, slovenšti spisovatelé aj. a všichni bývali krásami zdejšiho koutku Železných hor nadšeni." (ZÁKOUCKÝ, Karel. Výstřižky o Rudolfovi Pokornom, ohlasy [...]. Uložené v LA PNP v Prahe, fond Pokorný Rudolf).

13 ZELENKOVÁ, Anna: Op. cit., s. 72.

14 HOLEČEK, Josef: Podejme ruku Slovákům! Praha: Edvard Grégr, 1880, s. 26. Následné citáty tamže. 
a nemeckej literatúre, čo označil za obojstranne kontraproduktívne. S rovnakou hrozbou sa v súvislosti s nemeckou literatúrou konfrontovalo české prostredie. V otázke vedeckej literatúry sa s Pokorným názorovo zhodli. Holeček za hlavný rozdiel v slovenskom a českom prostredí považoval úplnú absenciu vedeckej literatúry a potencionálne úzky okruh čitatel'ov.

Holeček predložil krátku štúdiu, rozdelenú do šiestich tematicky zameraných kapitol. Slovákov a Čechov označil za českoslovanský kmeň (s. 28), pričom Slovákov vnímal ako vetvu jedného národa. Klúč ku vzájomnému fungovaniu našiel v jednote, spoločnom smerovaní a v práci. Absenciu zbližovacích tendencií pocitoval v jeho prirodzenom prostredí, „Čech bez Slováka tak dobře nic není, jako Slovák bez Čecha“ (s. 8). Roztrieštenost̉ vnímal ako nebezpečný faktor. Za slovenského iniciátora obnovenia vzájomných vztahov aj Holeček označil J. M. Hurbana a almanach Nitra, ktorý „byl českou kritikou štastně ubit“ (s. 8). Pokorný na znovuobnovenie Nitry reagoval miernejšie, podla neho publikovaním 6. a 7. ročníka almanachu „podal nám Čechům pravici, která ovšem nebyla pravici celého Slovenska, a tudiž, ač uvitána, přec jen s pravici českého národa zasnoubena nebyla". ${ }^{15}$

Holeček zastával názor že „slovenčina jest a zůstane nářč̌́m češtiny“. ${ }^{16}$ Priznal jej však zásluhy za nárast národného vedomia, ktoré chránilo pred mad’arizáciou, pričom Slovensko je „pouze odvětví literatury česke“" (s. 5). Aj napriek okliešteným možnostiam slovenskej literatúry ocenil slovenskú poéziu Jána Hollého a Sama Chalupku vnímal rovnocenne s K. J. Erbenom a F. R. Čelakovským (s. 19). Prostredníctvom slovenských autorov chápal prítomnosṫ slovenčiny ako potrebnú a vyzval aj k čítaniu slovenských diel: „Jinak býti nemůže, nebot' jako jsou v ohledu národopisném částí kmene našeho, ani v ohledu jazykovém jí být neprestávaji“ (s. 5). Zhodoval sa s Pokorným a tvrdil, „že v poesii mohou Slováci v službu bráti své nářeči bez ujmy českého jazyka a literatury“ (s. 23). Stotožnil sa s myšlienkou, že slovenčina pomôže Slovensku zveladit’ národnú svojbytnost'. Zbierku básní Cimbál a husle uviedol ako príklad vzájomného obohacovania, ale vyhranil sa voči miešaniu českých a slovenských slov.

Chápanie myšlienky slovanskej vzájomnosti bolo v Pokorného prípade postavené, okrem spoločnej historickej minulosti, aj na blízkych ludových tradíciách, jazykovej podobnosti či na snahe zachovat slovanské literárne špecifiká. Pri vytváraní vlastného názoru na česko-slovenskú vzájomnost̉ vychádzal z viacerých aspektov, jedným z nich bola aj myšlienka kultúrnej vzájomnosti J. G. Herdera, na ktorú v našom priestore nadviazal J. Kollár ${ }^{17}$ alebo menej známy František Cyril Kampelík ${ }^{18}$.

15 POKORNÝ, Rudolf: Op. cit., s. 16.

16 HOLEČEK, Josef: Op. cit., s. 14. Následné citáty tamže.

17 J. Kollár sa problematike venoval v štúdii O literárni vzájemnosti medzi kmeny a náréč́mi sláuskými (Hronka, 1846; O literárnej vzájomnosti. Red. Karol Rosenbaum. Bratislava: SAV, 1954). Podrobne sa dielom zaoberal aj BRTÁŇ, Rudolf: Vznik, vývin a verzie Kollárovej rozpravy o literárnej vzájomnosti. Liptovský Sv. Mikuláš: Tranoscius, 1942 alebo WEINGART, Miloš: Rozpravy o slovanské vzájemnosti. Praha: Slovanský ústav, 1929.

18 „V českých časopisech př́znivě komentovali každý nový projev probouzejicího se slovenského národního života: navazovali postupně styky s oběma jeho proudy - se stoupenci spisovné češtiny $i$ s bernolákovci. “ NOVOTNÝ, Jan: František Cyril Kampelík. Praha: Nakladatelství Melantrich, 1975, s. 31. Kampelíka mal k záujmu o Slovensko inšpirovat’ srbský spisovatel' Ivan Pačić. 
Pokorný, ktorý bol ovplyvnený primárne českým kultúrnym priestorom, až neskôr začal študovat’ slovenské kultúrne prostredie, pričom vychádzal aj zo znalostí o Slovanstve a slovanských literatúrach. V úvahe Literárni shoda československá názorovo polemizoval s ruským slavistom Antonom S. Budilovičom ${ }^{19}$, ktorý poukázal na potrebu zjednotenia slovanských jazykov, najmä kvôli zjednodušeniu komunikácie. To sa malo odrazit na podpore vedy a Pokorný uvedenú tézu aplikoval na česko-slovenskú otázku. Budilovičove stanovisko však považoval za otázne, v blízkej budúcnosti nerealizovatel’né. Skepticizmus prejavil s ohladom na prirodzený vývoj, možnú realizáciu našiel v politickom riešení. Nadviazal na stanovisko Martina Hattalu, ktorého považoval za Slováka aj Čecha. Hattala navrhoval vychádzat’ z chorvátsko-srbského nárečia, pričom podla Pokorného „otázka tato úzce souvisi s otázkou literárni jednoty československe".$^{20}$ Základná myšlienka Budilovičovho článku spočívala v prínose Cyrila a Metoda, pretože „přinesli Slovanům národni jazyk literární, který se stal všeslovanským“ (s. 53). Pokorný upozornil na vnútorné rozdiely a odlišný vývoj napr. západných Slovanov, ktorý „má tolik životni pružnosti, že by se pranic lekat nemusilo, kdyby se samo mezi sebou spojilo literárně, spravedlnosti a samostatnosti se domohlo“ (s. 54). Vychádzajúc z Budilovičových názorov, uvádza devät slovanských literatúr, ktoré dohromady nedosahujú vysoké číslo (nezapočítava Rusko, bez ktorého existuje asi 30 miliónov Slovanov). Pokorný nesúhlasil s tézou o nedostatočnom počte Slovanov v súvislosti s udržiavaním spoločného jazyka. Reagoval na odlišnosti, v Slovanoch prúdi „iná literárna krv“, porovnával ich s Talianskom, ktorého obyvatelia majú iný temperament. V závere úvahy vyjadril pochybnosti v súvislosti s dlhodobou udržatel’nostou malých slovanských literatúr, pretože Slovania majú odporcov na vonkajších hraniciach regiónov, ktorí usilujú o ich podriadenost'. „Dokončil jsem úvahu o literárni jednotě československé ve smyslu naši ,bibl[iotéky] československé‘ $i$ otisknu ji nejspišse ve ,Květech “ a nebo v sobě. Dnes četli jsme to u mne se zdejšimi Slováky. "21 Zámer vydat̉ Literárni shodu československú ako zvláštnu brožúru podnietilo zamietavé stanovisko oslovených časopisov: „Ve ,Květech“ mne nechali s článkem o liter[árním] sbližení zatím na holičách. "22

Po objasnení rôznych názorov a reakcií Pokorný preukázal, prečo by obnovenie češtiny na Slovensku nebolo úspešné, chcel „ukázati, že se obnova češtiny na Slovensku ani v poslednich letech nezdařila $i$ zdařit’ nemohla“". ${ }^{23}$ Tým sa usiloval podporit postavenie slovenčiny v českom kontexte, jeho kompromisné riešenie mohlo byt inšpirované česko-nemeckými vzt’ahmi v štyridsiatych rokoch 19. storočia, ked’ dvojjazyčnosṫ v Prahe bola prirodzená a do roku 1882 to bolo rovnako aj na univerzite. Zároveň to bola reakcia proti silnej mad’arizácii, ponuka využívania obidvoch jazykov symbolizovala obranu. Pokorný kritizoval českú nečinnost’, pozornost̉ obrátil na absenciu českých kníh a časopisov v chudobných oblastiach. Riešenie vnímal v šírení, predaji a výmene publikácií, k čomu vyzýval aj politickú scénu. Objektívne si uvedomoval rozvinutejšiu pozíciu českej literatúry a po

19 A. S. Budilovič bol ruský slavista (1846-1908). BUDILOVIČ, Anton Semenovič: O všeslovanském jazyku: kulturně-historická studie. Písek: vl. n., 1895.

20 POKORNÝ, Rudolf: Op. cit., s. 53. Následné citácie tamže.

21 R. Pokorný v liste J. Bottovi, 6. 4. 1880. Uložené v LA SNK v Martine, fond Botto Ján, sign. 23 A 41.

22 R. Pokorný v liste A. Heydukovi [nedatované]. Uložené v LA PNP v Prahe, fond Heyduk Adolf.

23 POKORNÝ, Rudolf: Op. cit., s. 35. Následné citáty tamže. 
mad’arizačných reštrikciách aj sţaženú pozíciu literatúry slovenskej. Vzhl’adom ku spoločenskému vývoju sa obával trvalého slovenského primknutia k mad’arčine, a preto prišiel so svojím programovým vyhlásením. Dôvodom vtedajšieho stavu bol podla autora dualizmus, ktorý bolo v českých silách zvrátit. Absencia uznávaných vedeckých a vzdelávacích inštitúcií spôsobila, že na Slovensku chýbali odborníci konkrétnych odvetví. ${ }^{24}$ „Slováci mlči už $i$ ke všemu, co se z naši strany jim podniká na prospěch“ (s. 39). Pokorný vyzdvihol osobnosti slovenského národného a literárneho života - Ludovíta Štúra, J. M. Hurbana, Andreja Sládkoviča, Sama Chalupku, Jána Botta, Janka Krála, Jána Palárika, Jána Kalinčiaka a d’alších (s. 33). Priniesol tiež hypotézu o slovenskom kultúrno-vzdelávacom pokroku, ktorý by v prípade fungovania Matice slovenskej nastal. Odvolával sa aj na Kuzmányho Hronku, Kollár „pokoušel se uváděti do češtiny jazykovou látku slovenskou“ (s. 25), čo sa nestretlo s pochopením. Neskôr sa ku slovenčine prihlásili Štúr, Hurban a Kalinčiak, pričom hlavným Štúrovým dôvodom bola „tzv. kmenovitost slovenská“ (s. 25) a samostatnost’ kmeňov a nárečí, ktorá, ak nefunguje, nemôže prispiet’ k celku (s. 25). Na nevyhnutnost’ zachovania slovenčiny upozornil z filologických aj geografických dôvodov. „Důvod Štúrưv na vzájemnosti slovanské snadno lze zvrtnout; [...] vždyt’ se vzájemnost uskutečnit’ může $i$ v jednom nárečr ‘ (s. 26). „Vinu“ rozdelil rovnomerne medzi lokality Čiech, Moravy aj Sliezska, základ bol v nedostatočnej podpore realizovanej iniciatívy. Zamyslel sa nad neexistenciou novín pre najchudobnejšiu čast̉ miestneho obyvatel'stva, slabé šírenie vzdelanosti a kritizoval nedostatok kníh, ktoré predstavujú duševnú podporu.

Pokorný v úvahe venoval pozornosț štyrom vybraným literárnym dielam, ktoré demonštrovali „pokodifikačný“ vývoj spisovného jazyka. Spis Hlasové o potřebě jednoty spisovného jazyka pro Čechy, Moravany a Slováky $(1846)^{25}$ sa jasne vymedzil proti kodifikovanej slovenčine. Z neho primárne vychádzal vo svojej teoretickej stati Literárni shoda československá aj Pokorný. Prezentoval názory Jána Kollára, ale poukázal aj na názory Vavrinca Benedikta z Nedožier, ktorý kritizoval Slovákov za l’ahostajný prístup k českým knihám. Odvolal sa aj na polyhistora Mateja Bela a Bohuslava Tablica, spomenul české osídlovanie slovenskej časti Uhorska a miešanie kultúr, ktoré vytváralo podmienky pre jazykové a náboženské obohacovanie. Rodný jazyk zostával prirodzeným spôsobom prejavu. Slovákov, podla neho, kritizoval za prístup k jazyku aj vzdelanec a zberatel' kníh Vavrinec Čaplovič, ${ }^{26}$ ktorý upozornil na príklon vzdelaných vrstiev k nemčine a latinčine. Tablic spolu s jazykovým osamostatnením predpokladal klesajúcu znalost̉ češtiny a nadväzujúcej vzdelanosti, čo Pokorný v zmysle osvojovania si češtiny potvrdil ${ }^{27}$ (s. 6). Pokorný v Hlasové... venoval pozornost̉ najmä Havlíčkovmu príspevku, kde zaujal kritické stanovisko voči Slovákom. Uznal Havlíčkovu prísnost', ale snažil sa vysvetlit jeho zámery a pochopit autorov postoj

24 „Prostonárodni bibliotéka“ nenahradi prý jim hvězdárstvo, země a prírodopis, slovozpyt aj. A kdež vezmou matematiky, historiky, hospodáře, právniky, lékaře atd." POKORNÝ, Rudolf: Op. cit., s. 37.

25 Podla Andreja Mráza je „priznačné, ako autor tejto úvahy pokladal za potrebné obšírne komentovat príspevky z protištúrovskej publikácie Hlasové a štúrovské reakcie na ne, usilujúc sa starý spor a argumenty $i$ zbrane v ňom používané aktualizovat'v zmysle svojich úsili“. MRÁZ, Andrej: Rudolf Pokorný a Slovensko. In: Literárnohistorický sborník. Bratislava: SAV, 1949-1950, s. 117. 
k Slovensku. Jungmanna považoval ako „klidného, důstojného genia“ (s. 12), ktorý spočiatku vnímal obojstranné jazykové obohacovanie, ale neskôr si prial posilnit pozície češtiny. Poukázal na dva hlavné body, odlišný Jungmannov prístup v porovnaní s ostatnými českými spisovatel'mi a časový vývoj v jeho chápaní problematiky (napr. aktivity bernolákovcov považoval za obohacovanie literatúry). Pokorný súhlasil, ale chcel väčšie zastúpenie češtiny v rámci výučby slovenčiny. Podarilo sa mu vierohodne zachytił aj Hurbanovo ideové smerovanie. Reagujúc na spoločenský vývoj sa Hurban za účelom „záchrany“ národa priklonil k návratu k češtine: „Hurban ov̌̌em r. 1876 vyznal, že se časy mění: dnes by měli Slováci z českého psáni dosti prospěchu; vždyt vědecké literatury svoji skoro ani vưbec nemaji a zapř́t nemohou, že jsou nuceni často se obsluhovat českou literaturou“ (s. 13). Neskôr už zostával názorovo v úzadí. Pokorný analyzoval aj názor P. J. Šafárika, ktorého označil za velkú osobnost' slovanského sveta. Za Šafárikovým stanoviskom je „blahodějná obnova a jistý zisk, nikoli odvážný, násilný přeurat a jistá škoda“ (s. 14). Pokorný preferoval pokojný, mierumilovný prístup, čo korešponduje aj s jeho navrhovanými riešeniami jazykovej otázky, rozdielny pravopis by nevyústil k rozvráteniu literárnej vzájomnosti a odkázal na Šafárikov slovenský pôvod a kompetenciu posúdit otázku v prospech Slovenska. Podla Pokorného sa obidva jazyky vyvinuli iným smerom, preto to považoval za neaktuálne. Na jazykové odcudzenie upozornil aj prostredníctvom diela Františka Palackého, ktorý zobrazil rozdiel medzi minulým a súčasným stavom a vo vzájomnej jazykovej príbuznosti vnímal (v porovnaní s minulostou) zhoršujúcu sa tendenciu.

Podobne ako Šafárik poukázal na rozdiely medzi Čechmi, Moravanmi a Slovákmi, tak z rovnakého názoru vychádzal aj Pokorný, nie všetci slovenskí kňazi si osvojili Hattalovu úpravu jazyka. „Hurban protestuje proti tomu, aby Němci byli nám v literární jednotě vzorem“ (s. 15). Upozornil aj na názorové premeny: „Hurban sám uznal po letech, že slovenský lid nadostač rozumi slovenštině (s. 15). Český slovakofil sa okrajovo zameral na slovenskú pasivitu a zamyslel sa, prečo Slováci neprijímajú slovanskú pomoc, ponúkanú „z príbuznosti“, bez nutnosti straty národnej identity. Uviedol aj znovu obnovený almanach Nitra, kladne prijatý zástancami česko-slovenskej vzájomnosti, ktorí neboli názorovo jednotní a museli sa vysporiadat's absenciou spoločného programového vyhlásenia. Zaoberal sa aj Kollárovým názorom, že by sa mala „slovenčina spojit’ s čěstinou, aby se společně pronikly, doplňovaly, ozdobovaly a obohacovaly“ (s. 17). Obidvaja sa, kvôli podpore slovenskej vzdelanosti, zhodli na nevyhnutnosti zakladat knižnice na Slovensku a pripomenuli záujem Slovákov čítat českú tvorbu.

Na výsledok Pokorného analýz vplýval aj generačný rozdiel a dobový posun. Autor považoval publikáciu L'udovíta Štúra Nárečja slovenskuo alebo potreba pisañja v tomto náreči za „zbytečnou“ (s. 22), ale zdôraznil, že osobnost Štúra rešpektoval. O to viac ocenil jeho dielo Slovanstvo a svet budúcnosti, ktorého rukopis bol v nemčine a v roku 1867 V. I. Lamanský pripravil preklad do ruštiny ${ }^{28}$. Tým vyvstáva otázka, či mal Pokorný k dispozícii nemeckú verziu, alebo ruský preklad Lamanského, o čom sa nám nepodarilo nájst zmienku. Zhodol sa so Štúrom, že slovenčina potrebuje viac pozornosti, podla Pokorného však Štúr vhodne neuchopil dôvody, prečo má slovenčina nárok na samostatnosṫ: „My

28 Porov. ZELENKOVÁ, Anna: Mýtus slovanstva a česko-slovenské vztahy v politickej reflexii L’udovita Štúra. (Na margo spisu Slovanstvo a svet budúcnosti). In: ZELENKOVÁ, Anna: Op. cit., 206-225. 
v tom svazku s nimi, jak jsme byli, i na dále zưstat, cokoliv znamenitého vyvedou (!) si osvojovat, s nimi v duševním spojeni stát a kde jim budeme moci co dobrého učinit', vykonat chceme, jakož to naopak od nich co bratrův očekáváme. " $29 \mathrm{~V}$ súlade so Štúrom odmietol jazykové prelínanie v literárnych textoch: „Ostatně souhlasíme, že by nap̌r. slovenská povidka nebo báseñ psána češtinou musila být tolik provitá slovenskými slovy, že by nebyla vlastně již ani českou ani slovenskou. Proto také naše Božena Němcová psala raději své slovenské pohádky slovenčinou“ (s. 22). V závere štúdie autor vyzdvihol dôležitost’ spisu Slovanstvo a svet budúcnosti, ktorý vnímal v rámci vyvíjajúcej sa česko-slovenskej literárnej jednoty. Zaujala ho Štúrova téza o rozdrobenosti dvoch literatúr, bez zjednotenia sa ani jedna nemala výraznejšie presadit (ani historicky). Poukázal na to, že stanovisko príklonu k ruskej literatúre nie je hlavnou myšlienkou diela. Štúr apeloval, že nie je dôvod, aby sa prestalo písat’ v lokálnych nárečiach, alebo aby sa tieto prestali používat' (za predpokladu, že sa spojenie zrealizuje). V závere však možnost’ vyhodnotil ako nepravdepodobnú, bránit mu mala slovanská „samolúbost“ (s. 22). Možnost’ spojenia našiel v rámci politických riešení.

Pokorný sa v súlade s projektom knižnej edície Knihovna československá snažil o uplatnenie jazykovej jednoty ,jmenovitě v Čechách a na Slovensku, navrhujeme ji v malém za literární jednotu československou a budeme ji prakticky provádět sami, Knihovnou československou؛ Neujme-li se v Čechách, na Moravě, ve Slezsku a na Slovensku tato myšlénka největších našich duchů československých pak - nevyspěli jsme ještě ani my [...]“ (s. 22). Vychádzal z prebiehajúcich slovanských diskusií, jeho riešenie si vyžadovalo zjednotenie dvoch historicky, jazykovo a kultúrne blízkych národností. V závere nepochyboval o tom, že vzájomné spojenie by obidvom stranám prinieslo výhody vo forme posilnenia aj v rámci medzinárodného postavenia. Je kritický ${ }^{30}$ voči nedostatku kníh medzi prostým obyvatel'stvom. Problém vnímal aj v českom prostredí a za vinníkov označil chudobu a nečinnosṫ: „Povinnosti naši a vlastním prospěchem jest, abychom krajiny podobné burcovali ze spánku záplavou - dobrých českých knih" (s. 22). Odsúdil však publikáciu Naše znovuzrozeni (1880) od Jakuba Malého, kde autor považoval rozkol po kodifikácii za súčasṫ dejín. Pokorný kritizoval najmä Malého neznalosṫ dobových pomerov. Knihu odmietol aj Jaroslav Vlček, pretože autor nepristupoval k otázke česko-slovenskej vzájomnosti otvorene a konštruktívne, čo neprispievalo k dosiahnutiu prezentovanej a spoločne s Pokorným formulovanej vízie zbližovania. ${ }^{31}$

Rudolf Pokorný informoval o pripravovanej úvahe Literárni shoda československá, obsahujúcej „sbližovaci názory a návrhy“, ${ }^{32}$ svojich spolupracovníkov z obidvoch častí Moravy. V diele „akceptoval slovenštinu jako nenahraditelný atribut národní existence a prostředek krásné literatury“. ${ }^{33}$ Vydanie diela pre nich nebolo prekvapujúce, očakávali predstavenie Pokorného vzájomnost’ podporujúcej vízie. Ludovít Rizner, Pokorného dlhoročný podporovatel', sa snažil využit dostupné možnosti na podporu jeho česko-slovenských aktivít.

29 POKORNÝ, Rudolf: Op. cit., s. 22. Následné citácie tamže.

30 „Na celém světě nemá naše národni neteč snad př̌kladu.“ Tamže, s. 22.

31 ŠMATLÁK, Stanislav: Op. cit., s. 173.

32 SVÍTIL-KARNíK, J. Výstřižky o Rudolfovi Pokornom, ohlasy [...]. Uložené v LA PNP v Prahe, fond Pokorný Rudolf.

33 OPELÍK, Jiří a kol.: Lexikon čské literatury. Osobnosti, díla, instituce. 3/I, M-O. Praha: Academia, 2000, s. 986. 
V korešpondencii sa zaujímal o vydanie druhého zväzku knižnej edície Knihovna československá, tú aj popularizoval v dobových periodikách. Informoval ho o ohlasoch na prvý zväzok edície, aj o prijímaní jeho programu na Slovensku, čo bolo dôležité z hladiska plánovania d’alších aktivít: „V 3-tom čísle ,Literárních Listov“ je Botto dost prajne posúdený a shoda česko-slovenská schválená. J. Vrána sa snád’ s podnikom tým konečne spriateli. [...] Na Martinčanoch, vidi sa mi, že tiež nemá ,shoda“ vel'kých priatel’ov. “34 Vzhl'adom k blízkemu pracovnému vztahu vedel o publikovaní tohto diela aj J. M. Hurban. Pokorný mu poslal úvahu spolu s knihami a Hurban ju okamžite prečítal ${ }^{35}$. Ocenil „inovatívnost"“ a vyzdvihol autorovo úsilie: „Obdivnejši pili v shledáváni těch rapsodii života našeho a klaním se Vaši lásce $k$ předmětu. Vaše Knižka je hranični sloup vývinu s tolika odpory potkávajicího se Slovenska. Bud' jméno Pána pochváleno, že Vám vnukl tak zdravé záliby. " ${ }^{36}$ Pokorný vysvetloval význam a podstatu spisu aj J. Škultétymu; vymedzil sa voči tomu, že Slovákov vníma ako „doplnenie“ českého národa, „jsme v̌̌ak dvě stejně rostlé větve jednoho kmenu československého z kořeni slovanských". ${ }^{37}$

Neznevažoval prácu Slovákov, ale zdôraznil, že pri pohlade „zvonku“ je náročnost’ pomerov očividná: „Vy doma jste již tak Mad’arstvem uhněteni, že v mnohém ohledu kráčíte o sto let pozadu za ostatnimi Slovany. U vás je dosud kněz hlavnim faktorem probouzení, a nebýt Vašich nadšených kněži, kde byste byli?" $38 \mathrm{~V}$ porovnaní s českým prostredím poukázal na posun odzrkadlujúci sa najmä v náboženskej otázke a hovoril, že Česi už túto etapu prekonali „a mysli svobodne“ ${ }^{39}$ Dospel k presvedčeniu, že je potrebné posielat čo najviac Slovákov na štúdium do Prahy, kde „naučili by se přece jen býti platnějšími, ráznějšimi Slováky“. ${ }^{40}$

Literární shoda československá vyvolala ohlas v dobovej tlači, napr. v časopise Čech ${ }^{41}$ bola Pokorného činnost hodnotená ako reflexia aktuálneho spoločenského diania v Prahe po zavedení spisovnej slovenčiny. Na dielo reagovali aj d’alšie periodiká, ako Našinec, ${ }^{42}$ Koleda, ${ }^{43}$ Plzeňské listy; ${ }^{44}$ Česká revue stručne formulovala hlavnú myšlienku - „můžeme žíti jednim životem kulturním $i$ při dvoji literatuře “. ${ }^{45} \mathrm{O}$ diele informoval aj časopis Paleček. Prínos štúdie vnímal aj J. Vlček: „Spisek je psán přehledně, jasně a poutavě; přáli bychom si pouze na konci jakési resumé všecho, stručnou bilanci všech hlasưv ještě jednou, čimž

34 L. Rizner v liste R. Pokornému, 7. 11. 1880. Uložené v LA PNP v Prahe, fond Sedlák Jan Vojtěch.

35 „Při zásilce posledni - Knih[ovny] českoslov[enské] a literstva, nečetl jsem ani psani dř́ve, až jsem hotov byl se ,Shodou“ “J. M. Hurban v liste R. Pokornému, 23. 5. 1880. Uložené v LA PNP v Prahe, fond Sedlák Jan Vojtěch.

36 J. M. Hurban v liste R. Pokornému, 23. 5. 1880. Uložené v LA PNP v Prahe, fond Sedlák Jan Vojtěch.

37 R. Pokorný v liste J. Škultétymu [nedatované]. Uložené v LA SNK v Martine, fond Škultéty Jozef, sign. 49 ACH 42.

38 Tamže.

39 Tamže.

40 Tamže.

41 HROBǍ̌, František: Válečné vzpominky ze Slovenska. Čech 48, 1923, s. 244, 5. 9.

42 Literárni shoda česko-slovenská... Našinec 12, 1880, č. 68, s. 3, 11. 6. [nepodpísané].

43 J.: Shoda československá. Koleda 5, 1880, č. 18, s. 285, 20. 6.

44 Literárni shoda československá. Plzeňské listy 16, 1880, č. 50, s. 3, 20. 6. [nepodpísané].

45 VOTRUBA, František: $K$ československé vzájomnosti v literatuře. Česká revue 8, 1915, č. 89, s. 549. 
by trest’ sporu a nejmarkantnějši důvody pro et contra jasněji vyšly najevo [...]“..6 Vyzdvihol zmapovanie dobových názorových spektier a publikovaných spisov. „Spisovatel rozebirá zde přesně všechny hlasy pro i proti od začátku sporu (1844), “47 s Pokorného riešením sa stotožnil a ako východisko zo situácie zopakoval dvojité používanie jazyka - ,jak s tím zajisté každý rozumný Slovák $i$ Čech bude souhlasiti“. ${ }^{48}$

Časopis Česká revue priniesol zamyslenie Františka Votrubu k česko-slovenskej literárnej vzájomnosti, z ktorej vyplývajúce nedorozumenia boli postavené na obojstrannej vnútornej nevyrovnanosti. ${ }^{49}$ R. Pokorný a J. Holeček v spisoch „navrhuji dvojjazyčnost, vědecká dila necht pišsi Slováci česky, lidová a poetická slovensky, a to do té doby, dokud nebude možno uvésti češtinu do škol“. ${ }^{50}$ Potvrdil to aj časopis Světozor, vychádzajúc z Holečkovho diela Podejme ruku Slovákům! - „úplně souhlasi Rud[olfa] Pokorného brožurka Literárni shoda československá, v nǐz se vykládaji přičiny a dějiny literárního rozkolu medzi Čechy a Slováky, "51 ktorý vyzdvihol praktický skutok - založenie knižnej edície Knihovna československá. Pokorného a Holečkov návrh sa hodnotí v Světozore ako „jediná to na ten čas rozumná cesta“ ${ }^{52}$ Obaja autori volali po väčšej pozornosti Slovensku; "Češi opustili Slováky úplnè!“53 Na Holečka sa Pokorný odvolal aj pri príprave edície: „Co my prakticky budeme provádèti ,Knihovnou československou‘, vyslovil také Josef Holeček v brožurce: ,Podejme ruku Slovákům!“"54 Pre R. Pokorného aj J. Holečka je charakteristický prienik vyplývajúci z ruchovskej orientácie. Pokorný sa snažil predložit „odbornú“ prácu, v kontraste je Holečkov ,jednoduchý“ spôsob podania problematiky a už v názve metaforicky stavia Slovensko do pozície „slabšieho brata“. Holeček publikoval svoju úvahu pár mesiacov pred Pokorným (1880). Obidvaja autori zvolili zhodné tematické zameranie, snažili sa o oživenie vzájomného česko-slovenského literárneho vztahu. Pokorný svoje názory aplikoval v praxi, ked' pristúpil k praktickému založeniu Knihovny československej. Holeček sa v spise snažil argumentovat, vychádzal z významných periodík a svoje dielo koncipoval zrozumitel'nejšie a prehl’adnejšie. Naplnil ruchovské štandardy, prikláňajúc sa k ludovému základu národa. Pokorný sumarizuje odbornú literatúru súvisiacu s problematikou vývoja spisovného jazyka, ktorého predelom je kodifikácia spisovnej slovenčiny v roku 1843; predkladá rešerše vybraných literárnych diel. Snažil sa prácu napísat vyváženejšie, odbornejšie, čo sa mu podarilo. Obidve práce vychádzajú z komparatívneho prístupu - či už sa jedná o českú verzus slovenskú „stranu/pohlad/prístup/vnímanie“, alebo sa porovnávajú pohlady interné. Práce sa líšia aj zvoleným štýlom, Holeček otvorene

46 VLČEK, Jaroslav: Rudolf Pokorný a literárni shoda československá. Urbánkův Věstník bibliografický 1, 1880 , č. 5 , s. 112 .

47 Tamže.

48 Tamže.

49 VOTRUBA, František: Op. cit., s. 549.

50 KÁLAL, Karel: Cesta zkázy a cesta spásy. Osvěta 33, 1903, č. 12, s. 1059.

51 S Holečkovým spiskem... Světozor 14, 1880, č. 22, s. 263, 28. 5. [nepodpísané].

52 Josef Holeček vydal... Světozor 14, 1880, č. 16, s. 191, 16. 4. [nepodpísané].

53 POKORNÝ, Rudolf: Op. cit., s. 9.

54 Tamže, s. 50. 
vyjadruje nesúhlas, ${ }^{55}$ čo mu zvolený žáner dobre umožňuje. Charakteristickým prienikom pre obidve diela je národná orientácia vychádzajúca z podpory širokých spoločenských vrstiev. Kritickejšie sa prejavili obidvaja autori ku vzdelaneckej vrstve. Pokorný v texte dielo Podejme ruku Slovákům! cituje a nachádza v ňom podporu svojho presvedčenia o nevyhnutnosti publikovania slovenskej vedeckej literatúry v češtine. Zároveň chcel rozšírit povedomie o Holečkovej práci v česko-slovenskom priestore.

Obom dielam sa venoval aj Jan Herben, ktorý bol ako realista silne ovplyvnený T. G. Masarykom; v tom sa od Pokorného a Holečka odlišoval. Holečkova úvaha „psána jest klidně, průzračně, “56 zatial' čo v Literárni shode československej vyzdvihol „horlivost', zápal a lásku k Slovensku“ (s. 285). Diela sa ale „navzájem doplňuji“ (s. 285). Herben súhlasil, s tým že Slováci „nejsou zvláštni národ [...] nýbrž jen větev česká“ (s. 285). Dôvody odlúčenia nachádza v odlišnom historickom vývine a otázku vzájomnosti vníma rozdielne aj v interných súvislostiach: „Vzájemnost Čech se Slovenskem nebyla nikdy tak čilá jako např. s Moravou" (s. 285). Autor tak považuje jazykové odcudzenie za prirodzené. Aj Herben sa stotožňoval s tvrdením, že práve postupná jazyková separácia bola príčinou vzájomného odcudzovania sa; napr. zástupcovia evanjelikov síce vychádzali z češtiny, ale nie z jej aktuálneho stavu. Kodifikáciu vnímal ako prirodzené vyústenie dlhotrvajúceho „sporu o jazyk“. Uvádza tri hlavné dôvody, prečo Slováci potrebovali vlastný jazyk - „vzkř́siti život slovenský, probuditi lid; [...] sjednotiti po celé zemi [...] odolati nátiskům mad’arštiny“ (s. 285). Pripomenul aj stanoviská J. M. Hurbana ${ }^{57}$, L. Štúra ${ }^{58}$ a M. M. Hodžu ${ }^{59}$. Herben vymenoval aj protiargumenty zo spisu Hlasové... a zamyslel sa nad oprávneným naplnením argumentov za slovenčinu. Uznal oživenie literárneho života, ktorý pozitívne ovplyvňoval slovenský národný život; ale rovnako intenzívne vnímal mad’arizáciu

Existujú názory, že Pokorného program neodpovedal dobovým štandardom a nedostatočne reflektoval históriu, „protože vycházel z jednotlivých osobnich kontakti̊, které mu neprinesly spolehlivý přehled dějin otázky československé a neukázaly mu plně stav shodný se skutečnosti “. ${ }^{60} \mathrm{~V}$ Pokorného chápaní došlo k posunu - myšlienka vzájomnosti nie je viac existenčnou otázkou, otázkou prežitia, ale otázkou d’alšieho vývoja. To v dobovom ponímaní prinieslo nový pohlad. Autor v texte odôvodnil zmysel práce, vydaním spisu podal zjednodušený obraz vývoja slovenskej literatúry, vývoja jazyka ${ }^{61}$ a objasnil, prečo sa na Slovensku nemohlo podarit’ obnovenie češtiny ${ }^{62}$. Venoval sa aj dobovým spoločenským

55 HOLEČEK, Josef: Op. cit., s. 9.

56 HERBEN, Jan: Shoda československá. Koleda 5, 1880, č. 18, s. 285, 20. 6. Následné citácie tamže.

57 „Slováci že jsou kmenem zvláštním (dovolávaje se Šafárika). “ Tamže, s. 286.

58 „Štúr mínil, že slovenčina zaslouži si toho, aby byla uchována a poznávána, a to již proto, že se v ni uchoval nejčistši duch slovansk. " Tamže, s. 286.

59 „[...] čěstina a slovenčina nejsou jedno z druhého, ale obě z jednoho a vyvinuly se jinak, a za druhé, že pojem slovanské vzájemnosti mluví pro slovenčinu. "Tamže, s. 286.

60 DAVID, Josef: Literárni pozustalost Rudolf Pokorný (1853-1887). Praha: LA PNP, 1978, s. 5.

61 „Aj v tejto štúdii chápe Pokorný československý pomer v základe v kategóriách literárnych a vel'mi dôrazne v kategóriách jazykových, pokračujúc tak v tradíciách osvietenského a romantického chápania národa. " MRÁZ, Andrej: Op. cit., s. 117.

62 Zámerom Pokorného bolo podporit slovenčinu „pro potřeby lidu slovenského a pro krásnou část literatury“. 
problémom ${ }^{63}$. Jeho filozofia sa nikdy úplne nenaplnila, ale argumenty mali určité opodstatnenie. Hoci sa odkaz česko-slovenskej jednoty na pozadí myšlienky slovanskej vzájomnosti nerealizoval, vývoj nasmeroval proces $\mathrm{k}$ väčšej globalizácii. Literárni shoda československá preukazuje Pokorného snahu pochopit slovenské pomery, geografické špecifiká a historické momenty, zaujímala ho prirodzená zmena a volil formu vzájomného zmierenia. Venoval sa klúčovým spisom a osobnostiam, snažil sa obsiahnut slovenské aj české názorové spektrum, sústredil sa na preukázanie súhlasných aj nesúhlasných stanovísk s ohladom na spisovný jazyk a jeho dalšie smerovanie. Historický význam Pokorného teoretických úvah spočíva aj napriek idealizácii v tom, že v dobovom diskurze podporil konštituovanie a další rozvoj slovenského literárneho jazyka na základe racionálne argumentovanej existencie slovenčiny ako relevantnej črty národnej identity a prostriedku krásnej literatúry.

\section{Primárna literatúra}

HOLEČEK, Josef: Podejme ruku Slovákům! Praha: Edvard Grégr, 1880.

POKORNÝ, Rudolf: Literárni shoda československá. Praha: Slavík a Borový, 1880.

\section{Literatúra}

BUJNÁKOVÁ, Jana: Odraz česko-slovenských vztahov v diele Rudolfa Pokorného. Dizertačná práca. Brno: FF Masarykovy university, 2020.

DAVID, Josef: Literárni pozuistalost Rudolf Pokorný (1853-1887). Praha: LA PNP, 1978.

HERBEN, Jan: Shoda československá. Koleda 5, 1880, č. 18, s. 285, 20. 6.

HROBǍ̌, František: Válečné vzpominky ze Slovenska. Čech 48, 1923, č. 244, s. 4, 5. 9. J.: Shoda československá. Koleda 5, 1880, č. 18, s. 285-286, 20. 6.

Josef Holeček vydal... Světozor 14, 1880, č. 16, s. 191, 16. 4. [nepodpísané].

KÁLAL, Karel: Cesta zkázy a cesta spásy. Osvěta 33, 1903, č. 12, s. 1059.

Literárni shoda česko-slovenská... Našinec 12, 1880, č. 68, s. 3, 11. 6. [nepodpísané].

Literárni shoda československá. Plzeňské listy 16, 1880, č. 50, s. 3, 20. 6. [nepodpísané].

MRÁZ, Andrej: Rudolf Pokorný a Slovensko. In: Literárnohistorický sborník. Bratislava: SAV, 19491950, s. 109-129.

NOVOTNÝ, Jan: František Cyril Kampelik. Praha: Nakladatelství Melantrich, 1975.

OPELÍK, Jiří a kol.: Lexikon české literatury. Osobnosti, díla, instituce. 3/I, M-O. Praha: Academia, 2000.

S Holečkovým spiskem... Světozor 14, 1880, č. 22, s. 263 [nepodpísané].

POKORNÝ, Rudolf: Op. cit., s. 35. Známy je Pokorného postoj, že slovenčinu podporoval (nie vo vedeckej literatúre).

63 Pokorný poukazuje na nedostatok kníh, časopisov, spolkov a kultúrneho života, čo by podnecovalo k väčšej aktivite a pozdvihnutiu národného života. 
ŠMATLÁK, Stanislav: Dejiny slovenskej literatúry II. 3. vyd. Bratislava: Literárne informačné centrum, 2001.

VLČEK, Jaroslav: Rudolf Pokorný a literárni shoda československá. Urbánkův Věstník bibliografický 1, 1880 , č. 5 , s. 112.

VOTRUBA, František: $K$ československé vzájomnosti v literatuře. Česká revue 8, 1915, č. 89, s. 549.

ZELENKOVÁ, Anna: Medzi vzájomnostou a nevzájomnostou. Sondy do česko-slovenských a slovensko-českých literárnych vztahov. Praha - Nitra: Slovanský ústav AV ČR, v. v. i. - FF UKF, 2009.

\section{Archívne materiály}

Literární archiv Památníku národního písemnictví, Praha; osobný fond Pokorný Rudolf; Sedlák Jan Vojtěch; Bílý František; Heyduk Adolf.

Literárny archív Slovenskej národnej knižnice, Martin; osobný fond Pokorný Rudolf; Vajanský Svetozár Hurban.

\section{Mgr. Jana Bujnáková, Ph.D.}

Ústav slavistiky

Filozofická fakulta, Masarykova univerzita

Arna Nováka 1, 60200 Brno, Česká republika

bujnak.jana@gmail.com 
